\title{
Adaptability of Released Potato (Solanum tuberosum L.) Varieties at Masha and Chena, South western Ethiopia.
}

\author{
Shamil Alo ${ }^{1 *}$ and Dereje Geremew ${ }^{2}$ \\ ${ }^{1}$ Ethiopian Institute of Agricultural Research (EIAR), Addis Ababa, Ethiopia \\ ${ }^{2}$ Tepi Agricultural Research Center, Po.Box 34, Tepi, Ethiopia
}

*Corresponding author: Shamil Alo, Ethiopian Institute of Agricultural Research

(EIAR), Addis Ababa, Ethiopia.

Received Date: February 24, 2021

Published Date: March 31, 2021

\begin{abstract}
Background: Rapidly increasing population pressure, widespread environmental degradation, recurrent drought, low productivity of the agricultural sector and limited market access have greatly contributed to critical food shortages in Ethiopia. These in turn have resulted in food insecurity, which is characterized by inability of the people at all times to have a physical and economic access to sufficient food to meet their dietary needs for a productive and healthy life. Therefore; this study was conducted to test the adaptability of improved potato varieties, identify and select the best high yielding and pest and disease resistant/ tolerant variety/ies for target area.

Methodology: Six released potato varieties were brought from Adet agricultural research center and evaluated during 2016 cropping season at two locations (Masha research site and Chena). Six released potato varieties were used for the experiment. The experiment was laid out in randomized complete block design replicated three times.

Results: The mean yield was ranged from 286.3 to 398.48 Quintal/ha for Shenkolla and Belete varieties respectively. Based on the recorded parameters Belete variety performed better than other varieties.

Conclusion: The findings of the study revealed that, the three varieties, Belete, Gera and Gudene were best performed than other varieties and will be recommended for the surrounding farmers for wider production. Further study should be carried out with improved varieties to improve potato production, especially in southwestern Ethiopia.
\end{abstract}

Keywords: Potato; Adaptability; Tepi; Southwestern ethiopia

\section{Background}

Irish potato (Solonaum tuberosum L.) is a starchy, tuberous crop of the Solanaceae family [1]. It is a crop of major economic importance worldwide [2]. Ethiopia has possibly the greatest potential for potato production; seventy percent of its arable land mainly in highland areas, above 1500 m.a.s.l., are believed to be suitable for potato. About $70 \%$ of the available agricultural land is located in an altitude of 1800-2500 m.a.s.l. and receives an annual rain fall of more than $600 \mathrm{~mm}$ which is suitable for potato production. In $2017 / 18$ cropping season, the total area under production is estimated to be $69,610.81$ hectares and the production is estimated to be $9,689,696.44$ quintals [3] and with an average national yield of $13.9 \mathrm{t} \mathrm{ha}^{-1}[4]$.

According to [5], of the total land areas of about 496, 148.99 hectares covered by root and tuber crops, 296,578 hectare $(\sim 60 \%)$ 
and of over 7.21 million tons of RTCs produced over 3.67 million tons $(\sim 51 \%)$ was covered with Potato. Potato has short cropping cycle and higher production per hectare per day when compared to other arable crops and it provides hope for improving the lives of millions of poor farmers in the risk-prone highlands [6]. In Ethiopia, potato is grown in a wide range of agro-ecological zones, throughout the year using different growing practices and is considered a "hunger breaking crop" because it can be grown and harvested when cereals don't mature for consumption other crops fail. Indeed, potato is the only food crop grown to any large extent in the dry season where rainfall is erratic and unpredictable in the months of March through May [7].

Globally, Potato ranks fourth after wheat, rice and maize crops with an estimated cultivated area of 19 million hectares with production of 332 million metric tons annually [8] and followed by cassava, sweet potato and yam from root and tuber crops [2]. Since the highlands are also home to almost over half of Ethiopian population, the potato could play a key role in ensuring national food security [9]. In Ethiopia, potato ranks first among the major tuber crop in volume of production and consumption followed by Enset, sweet potato, yam and taro [10]. Potato is grown in diverse soil types ranging from vertisol to nitosols in the highlands of Ethiopia.

The national average yield stands at $11.8 \mathrm{t} \mathrm{ha}^{-1}$ [11], which is low compared to the world's average productivity of $16.4 \mathrm{t} \mathrm{ha}^{-1}$ [13]. However, different biotic and abiotic factors are contributing for the low yield of Potato in Ethiopia. Of the contributing factors to the low yield and yield components of potato, substandard agronomic practices including suboptimum fertilizer amount application, use of substandard quality tubers and shortage of improved and adaptable cultivars are the major [12]. The growing importance of potato as a food crop is prefaced on rising food insecurity in the country. Increasing potato production on a sustainable basis will enable the crop to assert as a national strategic food security crop and help ease the food security challenges of the country. Rapidly increasing population pressure, widespread environmental degradation, recurrent drought, low productivity of the agricultural sector and limited market access have greatly contributed to critical food shortages in Ethiopia. These in turn have resulted in food insecurity, which is characterized by inability of the people at all times to have a physical and economic access to sufficient food to meet their dietary needs for a productive and healthy life.

Consequently, there is evidence of a reduced capacity to cope with expected setbacks in their economic or natural environments. The vast majority of the Ethiopian population depends mainly on cereal crops as food source. The food potential of horticultural crops, particularly that of root and tuber crops, has not yet been fully exploited and utilized despite their significant contributions towards food security, income generation, provision of food energy and resource base conservation [13].
On top of this, the root and tuber crops can also serve as source of cash income for low-income farm households and raw material for processed products for both rural and urban consumption. No country in sub-Saharan Africa has experienced a faster growth in Potato area than Ethiopia. The area under Potato cultivation is increasing at an average annual rate of $15 \%$. As in most developing countries, the growth in production of Potato was brought about by an expansion in acreage rather than productivity.

Three decades ago, Ethiopia's national potato area was estimated at 30000 hectares [14], reaching 50000 hectares by the mid 1980's, and 160000 hectares by 2001 [14]. Yet, during this same period average yields have only increased by 3 tons per hectare, from 5 tons per hectare in 1975 to 8 tons at present. These low yields are the consequence of multiple factors, including the use of unproductive, highly susceptible varieties subject to rapid degeneration by viruses, and limited use of sustainable integrated crop management (ICM) practices in potato cropping systems. National potato research programs in sub-Saharan Africa have continuously focused on selection of high-yielding varieties with resistance to late blight (LB) disease [15].

Potato holds a huge (largely ignored) promise for improving the livelihoods of hundreds-of-thousands of smallholder farmers in Ethiopia's risk-prone highlands. Potato has high potential for improving food security, increasing household income and poverty reduction. Despite these; the major problems include shortage of good quality seed tubers; lack of adaptable and disease-resistant varieties; inappropriate agronomic practices; poor storage, transport, and marketing conditions; declining soil fertility; and inadequate extension services [14].

Recently, the government of Ethiopia declared that Irish potato to be a national strategic food security crop [9]. This main policy pronouncement, qualified Irish potato for government-initiated farmer support initiatives supervised by Agricultural Research Centers through on farmer's plot seed multiplication and small scale semi-modern irrigation building. The growing importance of potato as a food crop is prefaced on rising food insecurity in the country. Increasing potato production on a sustainable basis will enable the crop to assert as a national strategic food security crop and help ease the food security challenges of the country.

Ethiopia is one of the principal potatoes producing countries in Africa and probably displays a unique position for having the highest potential area for cultivating potatoes. It is endowed with suitable climatic and edaphic condition for the production of high yield of potatoes. The crop is grown mainly during the rainy season and where irrigation is available and frost is not limiting, year-round production is also possible. The high lands are the most populated area of the country containing the majority of agricultural work force required for the sector. With the continuing increase in population and decline in the size of farm holdings, the 
major labor force has to move to labor intensive cropping system to sustain rural development and food production.

A number of production problems that account for the small area cropped with potato and the low national yield have been identified. The major ones are the concentration of potato cultivation in the highlands, unavailability and high cost of seed tubers, non-optimal agronomic practices, the prevalence of diseases and insect pests, and inadequate storage, transportation and marketing facilities [3]. Southwest Ethiopia is one of the region's high land areas that demands intervention efforts in line with improving potato productivity there by to have an input for the betterment of farmers of the area. Providing varieties which out yield the local variety is of paramount importance to increase accessibility of balanced food and household income.

To advance improvement of crop productivity in different localities, continual identification of the best and suitable crop technologies appeared to be essential. This can be achieved, through adaptability tests and generation of new technologies. Keeping this in view, the present study was conducted at Tepi Agricultural Research Center to test the performance of released Potato varieties for their adaptability in Tepi area.

\section{Material and Methods}

\section{Description of experimental site}

The experiment was conducted at Masha and Chena districts during 2015/2016 cropping seasons by Tepi Agricultural Research Centre. Tepi located in south western Ethiopia in SNNP Regional State at an elevation of 1200 meter above sea level and it is situated at Latitude of $7^{\circ} 10,54.5^{\prime \prime}$ and with a Longitude of $35^{\circ} 25,04.3-28.2$ E of Ethiopia. The research station receives an annual average rainfall of $1559 \mathrm{~mm}$ with maximum and minimum temperatures of $29.7^{\circ} \mathrm{C}$ and $15.5^{\circ} \mathrm{C}$, respectively. The soil of experimental site is reddish brown sandy clay loam classified as nitosol with $\mathrm{PH}$ range of 5.6 to 6.0 .

\section{Experimental materials and design}

The experiment was based on six released potato varieties which were obtained from Adet Agricultural Research center. Description of the experimental materials with their yield potential is shown in (Table 1) below. Randomized complete block design with three replications was used to conduct the experiment. Seed tubers were planted $75 \mathrm{~cm} * 30 \mathrm{~cm}$ spacing between rows and between plants respectively.

Table 1: Description of six potato varieties with their agro-ecological adaptations.

\begin{tabular}{|c|c|c|c|c|}
\hline \multirow{2}{*}{ Variety } & \multirow{2}{*}{ Altitude (m) } & \multicolumn{2}{|c|}{ Yield qt/ha } & \multirow{2}{*}{ Year of Release } \\
\cline { 3 - 5 } & & RM & $280-338$ & 2009 \\
\hline Belete & $1600-2800$ & 472 & 210 & 2006 \\
\hline Gudene & $1600-2800$ & 290 & - & 2003 \\
\hline Gera & $2200-3200$ & 259 & 291 & 2002 \\
\hline Jalene & $1600-2800$ & $2403-330$ & $220-225$ & 2002 \\
\hline Guassa & $2000-2800$ & 315 & 291 & 2005 \\
\hline Shonkolla & $1700-2700$ & & & \\
\hline
\end{tabular}

$\mathrm{RM}=$ under researchers 'management, $\mathrm{FM}=$ under farmers 'management.

Source: Ministry of Agriculture Crop variety registration bulletin (1987-2010).

Table 2: The Combined Mean Values of measured traits of tomato varieties at Masha and Chena.

\begin{tabular}{|c|c|c|c|c|c|c|c|c|c|c|}
\hline $\begin{array}{l}\text { Treat- } \\
\text { ments }\end{array}$ & $\begin{array}{l}\text { Stem Num- } \\
\text { ber per Plant }\end{array}$ & $\begin{array}{c}\text { Stem } \\
\text { Height }\end{array}$ & $\begin{array}{l}\text { Marketable } \\
\text { Yield per } \\
\text { Plot }\end{array}$ & $\begin{array}{c}\text { Total Yield } \\
\text { per Plot }\end{array}$ & $\begin{array}{c}\text { Total Yield } \\
\text { Qt/ha }\end{array}$ & $\begin{array}{l}\text { Av. Tuber } \\
\text { Number }\end{array}$ & $\begin{array}{l}\text { Av. Tuber } \\
\text { Weight }\end{array}$ & $\begin{array}{l}\text { Tuber } \\
\text { Width }\end{array}$ & $\begin{array}{l}\text { Tuber } \\
\text { Length }\end{array}$ & $\begin{array}{c}\text { Tuber Eye } \\
\text { Number }\end{array}$ \\
\hline Belete & $3.33^{\mathrm{b}}$ & $47.6^{\mathrm{ab}}$ & $35.79^{\mathrm{a}}$ & $35.86^{\mathrm{a}}$ & $398.48^{a}$ & $9.22^{\mathrm{a}}$ & $178.33^{\mathrm{a}}$ & $5.32^{\mathrm{a}}$ & $8.51^{\mathrm{a}}$ & $11.1^{\mathrm{a}}$ \\
\hline Guasa & $3.5^{\mathrm{ab}}$ & $42.16^{\mathrm{bc}}$ & $28.31^{\mathrm{cd}}$ & $30.02^{\mathrm{b}}$ & $333.56^{\mathrm{b}}$ & $6.61^{a}$ & $83.33^{c}$ & $4.54^{\mathrm{b}}$ & $6.68^{b}$ & $6.56^{\mathrm{b}}$ \\
\hline Shenkola & $2.56^{\mathrm{b}}$ & $37^{\mathrm{cd}}$ & $25.71^{\mathrm{d}}$ & $25.76^{c}$ & $286.3^{c}$ & $6.38^{a}$ & $120^{\mathrm{bc}}$ & $4.74^{\mathrm{b}}$ & $6.25^{\mathrm{b}}$ & $6.58^{b}$ \\
\hline Jalene & $4.3^{\mathrm{a}}$ & $36.63^{d}$ & $28.51^{b c}$ & $28.57^{b c}$ & $317.46^{b c}$ & $9.13^{\mathrm{a}}$ & $116.67^{\mathrm{bc}}$ & $4.56^{\mathrm{b}}$ & $6.8^{\mathrm{b}}$ & $6.69^{b}$ \\
\hline Gudene & $4.4^{\mathrm{a}}$ & $46.13^{a b}$ & $31.13^{\mathrm{b}}$ & $31.18^{\mathrm{b}}$ & $346.44^{\mathrm{b}}$ & $8.58^{a}$ & $118.33^{\mathrm{bc}}$ & $4.58^{\mathrm{b}}$ & $6.93^{b}$ & $6.76^{b}$ \\
\hline Gera & $2.93^{\mathrm{a}}$ & $50.13^{\mathrm{a}}$ & $34.83^{\mathrm{a}}$ & $34.88^{\mathrm{a}}$ & $387.57^{\mathrm{a}}$ & $8.75^{\mathrm{a}}$ & $141.67^{\mathrm{ab}}$ & $5.17^{\mathrm{a}}$ & $6.94^{\mathrm{b}}$ & $7.63^{b}$ \\
\hline $\mathrm{CV}$ & 22.6 & 10.52 & 7.24 & 9.27 & 9.27 & 32.91 & 36.13 & 6.31 & 13.32 & 15.65 \\
\hline LSD & 0.94 & 5.45 & 2.66 & 3.44 & 38.3 & 3.19 & 54.68 & 0.36 & 1.12 & 1.41 \\
\hline
\end{tabular}

\section{Data collected}

Data were collected on ten traits of potato varieties. Marketable and total tuber yield kg/plot, Stem number/plant at $50 \%$ flowering,
Stem height at $50 \%$ flowering, Stand count at harvest, Average tuber weight, Average. Tuber number/hill, Tuber eye number etc. Some important metrological data including mean monthly rain fall 
(mm), mean maximum and minimum monthly temperature, mean $\%$ relative humidity and soil type were recorded.

\section{Statistical analysis}

All necessary data were recorded and being subjected to analysis. Analysis of variance was performed using the ANOVA procedure of SAS Statistical Software. Effects were considered significant in all statistical if the P-values were $<0.05$. Means were separated using least significant difference test.

\section{Results and Discussion}

All varieties showed significant difference for stem number per plant, stem height, marketable yield per plot, total yield per plot, total yield quintal/ha, average tuber number/hill, average tuber weight, tuber width, tuber length and tuber eye number. Belete, Gera and Gudene gave highest yield followed by Guassa, Jalene and Shenkolla respectively. Gudene had highest stem number per plant followed by Jalene. Belete had highest marketable yield per plot, total yield per plot, total yield quintal/ha, average tuber weight, tuber width, tuber length and tuber eye number followed by Gera. Belete had highest average tuber number followed by Jalene. Gera had highest stem height followed by Belete.Yield per hectare showed significant difference among the varieties. The highest yield was obtained by Belete and the least yield was recorded by Shenkolla. This result is in agreement with the result which reported by [16] which stated that Belete variety was high yielder than other varieties at Haramaya location. Although, in contrary with the result reported by same authors at Hirna location which stated Gera variety was high yielder than Belete (Table 2).

\section{Summary}

The vast majority of the Ethiopian population depends mainly on cereal crops as food source. The food potential of horticultural crops, particularly that of root and tuber crops, has not yet been fully exploited and utilized despite their significant contributions towards food security, income generation, provision of food energy and resource base conservation [13]. Six released potato varieties were tasted at Tepi ARC in randomized complete block design with three replications during 2008 cropping season at two locations. The experiment was carried out to test the adaptability of improved potato varieties and identify and select the best high yielding, pest and disease resistant/tolerant variety/ies for the target area. The mean yield mean average tuber number and mean tuber length was ranged from 286.3 to $398.48 \mathrm{q} / \mathrm{ha}, 6.38$ to 9.22 and 6.25 to 8.51 for Shenkolla and Belete respectively. Based on mean yield, Belete, Gera and Gudene gave highest yield. The mean average tuber weight ranged from 83.33 gm to 178.33 for Guassa and Belete respectively. The mean tuber width ranged from 4.56 for Jalene to 5.32 for Belete. The mean tuber eye number was ranged from 6.56 to 11.1 for Guassa and Belete respectively [17-20].

All varieties showed significant difference for stem number per plant, stem height, marketable yield per plot, total yield per plot, total yield quintal/ha, average tuber number/hill, average tuber weight, tuber width, tuber length and tuber eye number. Belete, Gera and Gudene gave highest yield followed by Guassa, Jalene and Shenkolla respectively. Gudene have highest stem number per plant followed by Jalene. Belete have highest marketable yield per plot, total yield per plot, total yield quintal/ha, average tuber weight, tuber width, tuber length and tuber eye number followed by Gera. Belete had highest average tuber number followed by Jalene. Gera have highest stem height followed by Belete.Yield per hectare showed significant difference among the varieties. The highest yield was obtained by Belete and the least yield was recorded by Shenkolla. In general, Belete, Gera and Gudene were well adapted than other varieties and have to be multiplied and disseminated to users. Further study should be carried out with improved varieties to improve potato production, especially in Southwestern parts of Ethiopia [21,22].

\section{Conclusion}

Potato holds a huge (largely ignored) promise for improving the livelihoods of hundreds-of-thousands of smallholder farmers in Ethiopia's risk-prone highlands. Potato has high potential for improving food security, increasing household income and poverty reduction. Despite these; a set of constraints along the potato production has to be considered simultaneously, to ensure higher yields, better income, and a significant contribution of potato farming to food security, nutritional security and improved livelihoods in the country. The best adapted varieties like Belete, Gera and Gudene should have to be multiplied and disseminated to the area. Potato varieties that have high yielding, good resistance to late blight and low degeneration rate as well as good table and processing qualities have to be released and disseminated to boost potato production and productivity.

\section{Authors' Contributions}

SA initiated and executed the field experiment, managed and followed the field, collected data and wrote the manuscript. DG managed and followed the field and collected data.

\section{Acknowledgement}

Our special thanks go to Ethiopian Institute of Agricultural Research for financial support.

The contributions of individuals, who involved directly and indirectly in field follow up and data collection, are well acknowledged. Grateful acknowledgements are also due all farmers and daily laborers who toiled during the field experiments.

\section{Availability of Data and Materials}

All data generated from the study and reported in the manuscript are included in the article. Further data sets are available from the corresponding author upon request.

\section{Consent for Publication}

Not applicable. 


\section{Ethics Approval and Consent to Participate}

It is not applicable to this study.

\section{Funding}

The study was financed by Ethiopian Institute of Agricultural Research, and we are very grateful to it.

\section{Publisher's Note}

Springer Nature remains neutral with regard to jurisdictional claims in published maps and institutional affiliations.

\section{Conflict of Interest}

The authors declare that they have no competing interests.

\section{References}

1. Van den Berg RG, Jacobs MMJ (2007) Molecular Taxonomy. In: Vreugdenhil D, Bradshaw J, Gebhardt C, Govers F, MacKerron, D.K.L., MA Taylor, Ross HA (eds.), Potato Niology and Biotechnology. Advances and Perspectives. Elsevier. BV, Pp. 55-76.

2. FAO (2010) Crops.

3. MoA (2018) Plant variety release, protection and seed quality control directorate. Crop variety Register Issue number 21. June 2018. Addis Ababa, Ethiopia.

4. CSA (Central statistical agency) (2017/18) Agricultural sample survey, report on area and production of major crops of meher season for private peasant holdings. volume I, statistical bulletin 586. Addis Ababa, Ethiopia.

5. CSA (Central statistical agency) (2016) Agricultural sample survey, report on area, production and farm management practice of belg season crops for private peasant holdings. Volume V, Statistical Bulletin 578. Addis Ababa, Ethiopia.

6. FAO (2009) New light on a hidden treasure, Food and Agriculture Organization, Rome, pp.136.

7. Kolech SA, Halseth D, De Jong W, Perry K, Wolfe D, et al. (2015) Potato Variety Diversity, Determinants and Implications for Potato Breeding Strategy in Ethiopia. American Journal of Potato Research 92(5): 551566.

8. Faostat (2012) Disponível em. Acesso em, 14.

9. Fao, F.A.O.S.T.A.T (2008) Food and agriculture organisation of the United Nations. Retrieved on, 15.
10. Olango TM (2008) Ware Potato Production in Ethiopia: Current Status and Future Prospects Co-innovation for Quality in Agri-food Chains (CoQA). In Workshop, pp. 3-4

11. CSA (2013) Report on Area and production of major crops Thomas G Chastain Yield Components and Crop Yield.

12. Samuel Shaweno (2017) Effect of Combined Application of Biochar and Inorganic Nutrients ( $\mathrm{N}$ and $\mathrm{P}$ ) on Yield and Yield Components of Potato (Solanum tuberosum L.) at Gecha, Andiracha District, South western Ethiopia. MSc thesis Submitted to School of Graduate studies, Jimma University, Jimma, Ethiopia.

13. Gebremedhin W, Endale G, Berga L (2008) Overview of Trends in Root and Tuber Crops Research in Ethiopia in Root and Tuber Crops: The untapped Resources. (Eds.)

14. Gebremedhin W, Endale G, Kiflu B (2001) National potato research program report. Ethiopian Agricultural Research Organization,Holetta Agricultural Research Center.

15. Nakitandwe J, Adipala E, El-Bedewy R, Wagoire W, Lemaga B (2005) Adaptability of sift potato genotypes in different agro-ecologies of Uganda. African Crop Science Journal 13(2): 107-116.

16. Berhanu B, Tewodros M (2016) Performance evaluation of released and farmer's potato (Solanum tuberosum L.) varieties in eastern Ethiopia. Sky Journal of Agricultural Research 5(2): 38.

17. Gebremedhin W, Endale G, Berga L. Ethiopian Institute of Agricultural Research (EIAR). Pp. 1-5

18. Kinyua ZM, Smith JJ, Lungaho C, Olanya M, Priou S (2001) On-farm successes and challenges of producing bacterial wilt-free tubers in seed plots in Kenya. African Crop Science Journal 9(1): 279-285.

19. Lemaga B, Kanzikwera R, Kakuhenzire R, Hakiza JJ, Maniz G (2001) The Effect of crop rotation on bacterial wilt incidence and potato tuber yield. African Crop Science Journal 9(1): 257-266.

20. Struik PC, Wiersema SG (1999) Seed potato technology. Wageningen, Wageningen University Press.

21. Tesfaye A, Kiflu B, Chilot Y, Gebremedhin WG (2008) Socioeconomics and Technology transfer. In: Root and tuber crops: the untapped resources, Gebremedhin WG, Endale G, Berga L (eds). EIAR, Addis Ababa, Pp: 131152 .

22. Degebasa AC (2020) Assessment of plant growth regulators and chemicals for potato (Solanum tuberosum L.) dormancy breaking and subsequent yield in central highlands of Ethiopia 2(1): 10-20. 